\title{
VITAL SIGNS MEASUREMENT: AN INDICATOR OF SAFE CARE DELIVERED TO ELDERLY PATIENTS
}

\author{
Cristiane Chagas Teixeira ${ }^{1}$, Rafaela Peres Boaventura ${ }^{2}$, Adrielle Cristina Silva Souza ${ }^{3}$, Thatianny Tanferri de \\ Brito Paranaguá ${ }^{4}$, Ana Lúcia Queiroz Bezerra ${ }^{5}$, Maria Márcia Bachion ${ }^{6}$, Virginia Visconde Brasil ${ }^{7}$
}

\footnotetext{
${ }^{1}$ Master's student, Programa de Pós-Graduação, Faculdade de Enfermagem of Universidade Federal de Goiás (UFG). Goiânia, Goiás, Brazil. E-mail: cc-teixeira@hotmail.com

${ }^{2}$ Master's student, Programa de Pós-Graduação at the Faculdade de Enfermagem, UFG. Goiânia, Goiás, Brazil. E-mail: rafaelaboaventura@gmail.com

${ }^{3}$ Master's student, Programa de Pós-Graduação, Faculdade de Enfermagem, UFG. Goiânia, Goiás, Brazil. E-mail: enfeadrielle@ gmail.com

${ }^{4}$ Doctoral student, Programa de Pós-Graduação, Faculdade de Enfermagem, UFG. Goiânia, Goiás, Brazil. E-mail: ttb.paranagua@ gmail.com

${ }_{5}^{5}$ Ph.D. in Nursing, Programa de Pós-Graduação, Faculdade de Enfermagem of UFG. Goiânia, Goiás, Brazil. E-mail: analuciaqueiroz@ uol.com.br

${ }^{6}$ Ph.D. in Nursing, Professor, Programa de Pós-Graduação, Faculdade de Enfermagem of UFG. Goiânia, Goiás, Brazil. E-mail: mbachion@gmail.com

${ }^{7}$ Ph.D. in Nursing, Professor, Programa de Pós-Graduação, Faculdade de Enfermagem of UFG. Goiânia, Goiás, Brazil. E-mail: visconde@ufg.br
}

\begin{abstract}
The study's aim was to analyze the importance assigned by the nursing staff to the recording of vital signs of elderly inpatients, as well as perceived barriers and benefits. Data were collected through interviews held with 13 nurses and the reports were analyzed using content analysis, considering the health belief model proposed by Rosenstock. The categories that emerged from the analysis indicate barriers that interfere in the proper monitoring of vital signs, namely: workload, lack of availability and accessibility of basic equipment such as thermometers, stethoscopes and sphygmomanometers, which compromises the nursing assessment and leads to a greater susceptibility to incidents. Although the facility does not provide conditions to measure vital signs properly, the nursing staff attempts to do what is feasible given their current knowledge and context to achieve the best outcome possible in view of the resources available. DESCRIPTORS: Quality of health care. Health of the elderly. Vital signs. Nursing records.
\end{abstract}

\section{AFERIÇÃO DE SINAIS VITAIS: UM INDICADOR DO CUIDADO SEGURO EM IDOSOS}

RESUMO: O estudo objetivou analisar a importância atribuída, as barreiras e os benefícios percebidos pela equipe de enfermagem, relacionados ao registro dos parâmetros dos sinais vitais em idosos hospitalizados. Os dados foram coletados por meio de entrevista com 13 profissionais de enfermagem e as falas foram analisadas pelo método de interpretação de sentidos, considerando o modelo de crenças em saúde de Rosenstock. Das categorias emergidas, identificamos barreiras que interferem na verificação adequada dos sinais vitais, tais como a sobrecarga de trabalho, a disponibilidade e acessibilidade a materiais básicos como termômetro, estetoscópio e esfigmomanômetro, comprometendo a avaliação de enfermagem e acarretando maior susceptibilidade aos incidentes. Ainda que a instituição não forneça condições para a aferição adequada dos sinais vitais, desvela-se que a equipe de enfermagem tem tentado fazer o que é viável diante do conhecimento atual e do contexto inserido, na tentativa de alcançar o melhor resultado possível, mediante os recursos disponíveis.

DESCRITORES: Qualidade da assistência à saúde. Saúde do idoso. Sinais vitais. Registros de enfermagem.

\section{LOS SIGNOS VITALES COMO UN INDICADOR DE LA ATENCIÓN SEGURA EN PERSONAS DE EDAD AVANZADA}

RESUMEN: El estudio tuvo como objetivo analizar la importancia, las barreras y beneficios percibidos por el personal de enfermería, relacionada con el registro de los parámetros de signos vitales en ancianos hospitalizados. Los datos fueron recolectados a través de entrevistas con 13 enfermeras y las líneas fueron analizadas por el método de interpretación de sentido, teniendo en cuenta el modelo de creencias de salud Rosenstock. De las categorías que surgieron, identificamos las barreras que interfieren con el buen control de los signos vitales, tales como la carga de trabajo, la disponibilidad y accesibilidad de los materiales básicos, como el termómetro, estetoscopio y esfigmomanómetro, comprometiendo la valoración de enfermería y que resulta en una mayor susceptibilidad a los incidentes. Aunque la institución no ofrece condiciones para una medición adecuada de los signos vitales se revela que el personal de enfermería ha tratado de hacer lo que es factible dado el conocimiento actual y el contexto se inserta con el fin de lograr el mejor resultado posible los recursos disponibles.

DESCRIPTORES: Calidad de la atención de salud. Salud del anciano. Signos vitales. Registros de enfermería. 


\section{INTRODUCTION}

Vital signs are indicators of one's health condition and an assurance of proper circulatory, respiratory, neural and endocrinal functions. Vitals signs are a mechanism to universally communicate a patient's condition and severity of disease. These parameters, serially measured, help nurses to identify nursing diagnoses, assess interventions, and make decisions concerning the response of patients to treatment..$^{1-2}$

In the context of care provided to elderly individuals, vitals signs are indicators that require special attention due to considerable variation these individuals experience in their physiological, cognitive and psychosocial health. Vitals include the physiological measurement of blood pressure, heart rate, respiratory frequency and temperature. ${ }^{1}$

The measurement of blood pressure among elderly individuals should be taken with the same care provided to young adults. This parameter is technically measurable with the use of sphygmomanometers and stethoscopes. ${ }^{3}$ According to the $6^{\text {th }}$ Brazilian Guidelines on Hypertension, ${ }^{4}$ one's blood pressure is satisfactory when systolic blood pressure is below $130 \mathrm{mmHg}$ and diastolic blood pressure is below $85 \mathrm{mmHg}$. Heart rate is routinely assessed based on the radial pulse over a period of 60 seconds and the normal parameter is between 60-100 beats per minute. Respiratory frequency has semiotic meaning when more than 24 breaths per minute $^{3}$ and normal body temperature is between 36 and $37^{\circ} \mathrm{C} .{ }^{5}$

Monitoring these parameters is important because of the high risk of altered thresholds as a result of aging, considered the phase of greatest vulnerability due to age and comorbidities ${ }^{6-7}$ Due to the loss of homeostasis protection mechanisms related to senescence, elderly individuals are more vulnerable to the after-effects of diseases, which contribute to longer hospitalizations and greater costs for the healthcare services. ${ }^{8-10}$

The purpose of serially assessing a patient's vitals signs is to prevent harm and the early identification of events with a potential to affect the quality of healing actions. Additionally, the identification of these parameters helps to reduce the risk of unnecessary harm associated with healthcare delivery to an acceptable level, ${ }^{11}$ by achieving quality care and patient safety, which are priorities for all the professionals involved in the care process.
Complete assessment and recording, however, remain a great challenge for the nursing staff and healthcare services. ${ }^{12-13}$ Failure to record the vitals signs of patients in medical records hampers the communication of information, which compromises the assessment of nursing interventions and care delivery. ${ }^{9-10,14}$ When providing care to elderly patients, healthcare providers are expected to take observation and patient-professional relationships beyond what is traditionally done, given the vulnerability and specificity associated with changes that take place due to aging.

Even though the nursing staff is legally required to clearly and completely record on patients' medical charts all the procedures performed in a standardized and identifiable manner, ${ }^{15}$ there is a need to rigorously assess the consistent recording in nursing practice in order to avoid potential harm to patients. ${ }^{16-18}$ Studies show that elderly individuals are more susceptible to incidents, ${ }^{17,19-21}$ and also report the occurrence of events after incomplete recording of vitals signs, ${ }^{22-23}$ especially respiratory frequency, which is usually the least frequently documented vital sign. ${ }^{24-25}$

One ongoing study addressing records of 260 hospitalizations of elderly individuals in a surgical clinic identified 5,321 incidents, $71 \%$ of which involved incomplete recording of vitals, while the non-recording of respiratory frequency $(39.4 \%)$ also stood out. The literature also reports incomplete recording of vital signs among elderly individuals in this same context. ${ }^{26}$

Even though measuring one's vitals signs is a simple task, neglecting it may interfere in the evolution and outcome of a patient's clinical and surgical condition. It is an independent and routine procedure performed by the nursing staff because it does not require specific equipment, while all the remaining health providers within the staff utilize its results. For this reason, some questions emerge regarding the reasons of this situation, since nursing workers are also responsible for providing individualized care and safe practices.

Therefore, understanding the factors that influence the measurement and incomplete recording of vitals signs among elderly individuals is essential due to the vulnerability of this population with potentially severe outcomes; in this way, people can reflect upon and direct strategies that enable the incorporation of safe practices in order to achieve higher quality care delivery. Therefore, 
this study's aim was to analyze the importance the nursing staff attributes to recording vitals signs measurements among hospitalized elderly individuals, and the barriers and benefits they perceive in regard to this procedure.

\section{METHOD}

This descriptive study with a qualitative approach was conducted in June 2014, in a university hospital in the Midwest region of Brazil, a referral hospital for highly complex surgical procedures.

The study population included 13 nursing workers: four RNs and nine nursing technicians. The participants were randomly drawn from a job schedule considering different work shifts to ensure the participation of workers from different shifts.

The saturation criterion was used to establish the number of participants, i.e., the inclusion of new participants would not provide new content or significantly contribute to reflection upon the theme. ${ }^{27}$

Data were obtained through individual interviews held in a private room and responses were recorded after obtaining consent. The following questions guided the interview: "In your opinion, what is the importance of measuring vital signs in elderly individuals in your daily practice?"; "What are the factors that facilitate and those that hinder this practice in your working environment?"

Data were fully transcribed to compose the corpus of analysis and coded with the letter E followed by a cardinal number according to the order of interview.

The transcribed material was exhaustively read in order to perform content analysis, ${ }^{28}$ a thematic modality that suggests the identification of categories based on pre-analysis, exploration of material, treatment, inference, and interpretation of results. Thematic categories were predetermined based on the Health Belief Model proposed by Rosenstock, ${ }^{29}$ which proposes analysis be conducted in four dimensions:

Perceived susceptibility: refers to a subjective perception of risk that a person will acquire a given condition or disease.

Perceived severity: it is assessed both by the degree of emotional stimulation that is created around it and by the biological, social, emotional, and financial consequences it may lead to.
Perceived benefits: refer to a belief in the effectiveness of actions and on the perception of positive results and perceived barriers.

Perceived barriers: refer to negative aspects perceived by the individual in regard to health actions. The individual may perceive these actions to be expensive, inconvenient, unpleasant, painful, or that they demand time. When actions are qualified this way, they become barriers and create conflictive motives.

This study is linked to the project "Analysis of occurrences of adverse events in a hospital of the sentinel network in the Midwest region" approved by the Institutional Review Board at the Hospital das Clinicas at the Federal University of Goias, Brazil (protocol n. 064/2008). Ethical aspects followed the guidelines of Resolution 466/2012, Brazilian Council of Health. ${ }^{30}$

\section{RESULTS AND DISCUSSION}

A total of nine nursing technicians, two men and seven women, along with four RNs, two men and two women, participated in the study. Age ranged from 24 to 58 years old and four of these worked on the night shift. Time working in the institution ranged from up to five years for four workers, between six and 11 years for another four workers, and 12 years or more for five workers. Five professionals had more than one job.

Two categories and four subcategories emerged from the Health Belief Model's dimensions: ${ }^{29}$ "monitoring vital signs in elderly individuals", the subcategories of which are "need to control clinical state" and "vulnerable clinical state"; "safety care provided to elderly patients", with the subcategories "shortage of personnel and material" and "personal actions to continue the process".

\section{Monitoring vital signs in elderly individuals}

The monitoring of vital signs includes monitoring and controlling parameters regarding blood pressure, heart rate, respiratory frequency, and temperature, which can vary among elderly individuals due to vulnerability associated with aging. This category emerged from responses concerning the importance the staff assigned to the measurement of vitals signs, grouped according to perceived severity (need to control clinical state) and perceived susceptibility (vulnerability of clinical state) (Table 1). 
Table 1 - Synthesis of nursing workers' reports regarding the importance of measuring vital signs in elderly individuals, classified according to the dimensions of the Health Belief Model proposed by Rosenstock

\begin{tabular}{|c|c|c|c|}
\hline ategory & Subcategories & Dimension & Representative reports \\
\hline 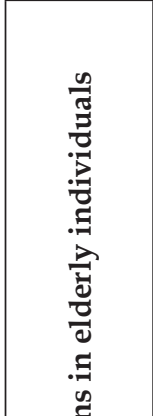 & $\begin{array}{l}\text { Need to control } \\
\text { the clinical state }\end{array}$ & $\begin{array}{c}\text { Perceived } \\
\text { severity }\end{array}$ & $\begin{array}{l}\text { [...] Monitoring patients to know whether they have some type of intercurrence } \\
\text { or instability so we can call the physician and intervene [...] (E6); } \\
{[\ldots] \text { It's important because you are verifying how the patient is doing [...] (E5); }} \\
\text { I think it's essential... the most important care we have to provide to an elderly } \\
\text { patient is to check vital signs (E7); } \\
{[\ldots] \text { to have reliable parameters, you have a more rigorous measurement of vital }} \\
\text { signs (E8); } \\
{[\ldots] \text { a colleague from the night shift may lead you to think that she's measured }} \\
\text { the blood pressure but she actually did not [...] (E10); } \\
{[\ldots] \text { the sphygmomanometers get out of calibration often so you are not sure }} \\
{[\ldots] \text { (E5). }}\end{array}$ \\
\hline 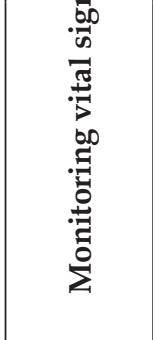 & $\begin{array}{l}\text { Vulnerability of } \\
\text { clinical state }\end{array}$ & $\begin{array}{c}\text { Perceived } \\
\text { susceptibility }\end{array}$ & $\begin{array}{l}{[\ldots . .] \text { elderly individuals are more likely than young individuals to have prob- }} \\
\text { lems. Because usually surgery in elderly individuals is more difficult than in } \\
\text { young people [...] (E11); } \\
{[\ldots] \text { you have to be more attentive with elderly patients, especially with those }} \\
\text { who are hypertensive, use continuous medication. Sometimes, their blood pres- } \\
\text { sure is really low and sometimes it's really high [...] (E12); } \\
{[\ldots] \text { It is very important because elderly individuals are less stable than young }} \\
\text { patients. So, for me, for you to have a reliable parameter; you have to take vitals } \\
\text { with more rigor [...] (E13). }\end{array}$ \\
\hline
\end{tabular}

Elderly patients present differentiated physiological and physiopathological conditions due to age and have specific characteristics, such as pathologies, that more frequently affect the musculoskeletal system and senses than in the case of younger patients. Hence, the health of older patients depends on the support and follow-up of specialized professionals that is appropriate to these patients' context. $^{31}$ The synthesis of responses indicate that nurses and nursing technicians consider necessary to control patients' clinical state, revealing the importance of vital signs for daily practice, and recognizing the vulnerability of the elderly patients' clinical state.

The perception of each individual is related to beliefs and behaviors subjectively acquired and incorporated into his/her social life. ${ }^{32}$ Given this context, we note the influence of these beliefs as a favorable indicator in health practice.

Even though perceptions change from person to person, we verified in this study's setting that the perception of susceptibility and seriousness of "monitoring of vital signs in elderly individuals" may be a positive determinant for the behavior of nursing professionals. The decision-making of healthcare providers is based on the fragility, vulnerability, and dependence of elderly individuals when their autonomy is limited. One's behavior may be based on a natural need to ensure positive results concerning one's beliefs or rules and censorship imposed by the society.

Susceptibility and seriousness were expressed by feelings such as a concern over changing vital signs and the reliability of parameters measurements, expressed in reports that highlighted a lack of maintenance of equipment such as sphygmomanometers, stethoscopes, as well as lack of thermometers. This feeling expressed doubt and insecurity on the part of professionals in regard to the reliability of measurements, showing an acknowledgement of the risks to which patients are exposed. It leads us to reflect upon the need for a service that connects the practice of workers and maintenance of devices in order to obtain actual and comprehensible measurements.

Preventive and corrective maintenance alone is not useful if not effectively linked to a system of human resources administration with improved professional performance, itself ensured through training and supervision of nursing actions. It is necessary to ensure that all personnel who compose the staff perform their work in a quality manner, meeting standards of conformity and performance of equipment in an efficiently and operationally utilize equipment. It is only possible to 
provide dignified care if there is a dignified work ambience, i.e., in the presence of well-managed technical conditions, human capital, and material resources in order to achieve effective processes in healthcare delivery. ${ }^{33}$

On the other hand, discontinuity of care expressed by incomplete records regarding vital signs during the night shift for elderly individuals reinforces that there is a distance between the good discourse reported in the interviews and the actual practice expressed in many reports.

\section{Safety care provided to elderly individuals}

This category emerged from responses concerning safety care, which were grouped according to perceived barriers (shortage of equipment and material) and perceived benefits (personal action to continue the process) (Table 2). It includes themes that referred to organizational and managerial aspects, which are necessary to reduce unsafe techniques in care processes and to use better practices in order to achieve better outcomes for patients. ${ }^{34}$

Table 2 - Synthesis of the nursing workers' reports regarding safety care provided to patients, classified according to the dimensions of the Health Belief Model proposed by Rosenstock

\begin{tabular}{|c|c|c|c|}
\hline Category & Subcategory & Dimension & Representative reports \\
\hline 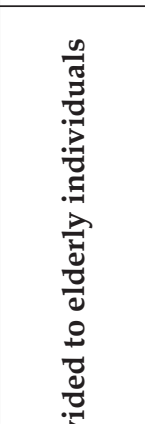 & $\begin{array}{c}\text { Shortage of } \\
\text { personnel and } \\
\text { material }\end{array}$ & $\begin{array}{c}\text { Perceived } \\
\text { barriers }\end{array}$ & 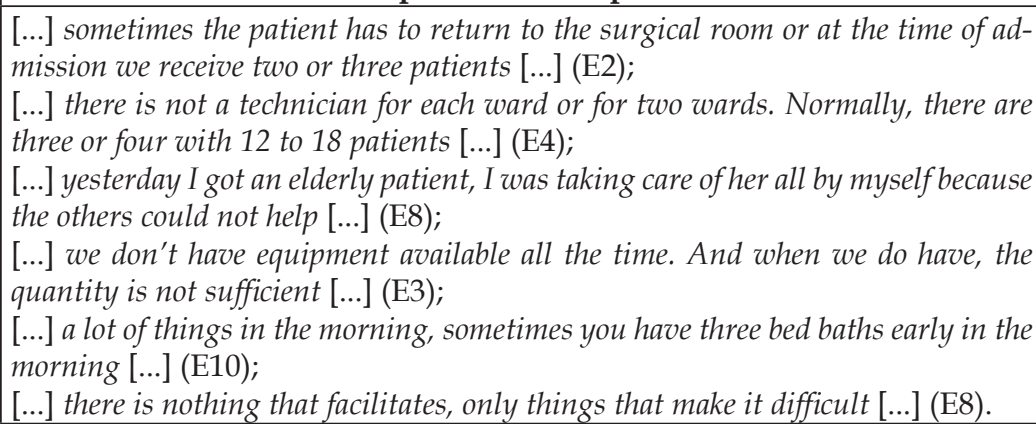 \\
\hline 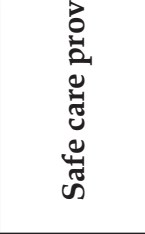 & $\begin{array}{c}\text { Personal actions } \\
\text { to continue the } \\
\text { process }\end{array}$ & $\begin{array}{l}\text { Perceived } \\
\text { benefits }\end{array}$ & $\begin{array}{l}\text { [...] the facility is that the people are bringing, they are bringing equipment from } \\
\text { home [...] (E4); } \\
{[\ldots] \text { when we buy our own equipment. We buy our thermometers and vital signs }} \\
\text { devices, in this case, blood pressure [...] (E9); } \\
{[\ldots] \text { But in the end, even though there is not enough, despite all difficulties, all }} \\
\text { vitals are verified [...] (E6). }\end{array}$ \\
\hline
\end{tabular}

Mentioning the use of equipment that is property of the workers themselves as a facilitator was remarkable. The participants' reports are very similar; that is, they consider this attitude necessary to comply with basic activities of their duties, which shows they experience limitations and contingencies that impede the correct practice of any activity. Many of the participants expressed dissatisfaction with their current work context within the facility even as they conform to it.

Often, in this context, when workers try to perform a complete monitoring of parameters, they use alternative means to meet the service needs, usually because material resources are unavailable. This may impede quality care delivery, which is necessary for the patients' early recovery.

Numerous barriers perceived by the nursing staff in the workplace can nullify positive efforts, negatively influencing the complete monitoring of vital signs. The most frequent obstacles in- cluded: lack of and inaccessibility to material and equipment such as thermometers, stethoscopes, and sphygmomanometers, in addition to work overload and stress, evidenced in the subcategory "shortage of personnel and material".

The participants believe that the fact that they work without basic working conditions being provided reflects neglect on the part of the institution toward the staff and patients, demotivating the workers. In this context, patient safety is compromised within managerial and organizational practice and imposed as potential risks for patients, compromising appropriate healthcare delivery. Based on this assumption, the implementation of knowledge, technology and the relationships of the staff with patients, seem to be faulty, compromising the Donabedian conception that these domains determine quality of health care delivery. ${ }^{35}$

Even though the facility does not provide conditions for the nursing staff to properly mea- 
sure vital signs, we verified that many of the nursing professionals have tried to do what is feasible considering current knowledge and their organizational context in an attempt to achieve the best outcome possible in the face of the resources available. This behavior is apparent in the report of several of the participants, which reveals a feeling of instability and frustration in the face of limited resources that impedes the proper performance of working processes. Despite different values, professionals imply that the mobilization of the staff, through motivation and proper working conditions, would enable changes to be made in the facility and suggest changes and financial investment would be required on the part of competent agencies.

The evidence presented by the professionals in this study leads us to reflect upon proposals found in other studies regarding continuing education to transform professional practices. ${ }^{36-38}$ Education per se does not lead to positive results when not associated with a minimally adequate organizational structure and when disseminated to professionals who are not motivated to improve their practices. The beliefs held by workers in regard to the availability and effectiveness of their actions is what determines the initiative and direction of their actions. ${ }^{29}$ It can be frustrating to work without minimal standards that enable quality care, which leads to a greater susceptibility to incidents.

Similarly, we clarify that the organizational dynamics of work in the surgical clinic generates overload and occupational stress while, on the other hand, there is a culture on the part of the staff in which they trivialize the current work dynamic concerning the complete measurement of vitals signs. It is possible that little connection is established between academic activities and the facility itself, though this connection is essential for actions in this field. This search for relationships is necessary for us to reflect upon interventions on the part of the management in order to devise strategies able to effectively reorganize the work process and minimize the risk of incidents to which elderly patients are exposed.

\section{CONCLUSIONS}

This study's objectives were achieved since it was possible to identify the importance the nursing staff assigns to the measurement of vital signs and also to identify barriers that impede this action from happening and the benefits generated by this issue. This study has some limitations, as it does not present the estimative and exact causes of failures related to the process of measuring vital signs and is restricted to each professional's personal view. The analysis of reports, however, brings important contributions to nurses around the world, encouraging reflection upon the work process and indicators that direct decision-making. Because this is a qualitative study and based on the results obtained, we consider the method chosen was effective to direct the path followed by the researchers.

As the main results we observed that that the nursing staff values the measurement of vital signs in elderly individuals and relates its importance to aging-related vulnerability and susceptibility. On the other hand, failures regarding the continuity of care, and unsafe actions are observed due to the poor quality, lack of maintenance, and availability of material and personnel, which hinders the effective delivery of care. In response to the problem, the workers assume co-responsibility and, in an attempt to ensure safety and continuity of care, provide material required with the own funds. Even though the professionals' behavior benefits the patients, it shows there is an immediate need of greater investment in health services on the part of governmental agencies.

We verified that, in general, when mobilized, the professionals are able to transform realities and value subjective and social dimensions of the multidisciplinary work, engaging in the development of coping strategies to obtain improved results in health practice. It is not, however, the role of healthcare workers only to develop actions that are coherent with health delivery, but it is especially the role of competent agencies to systematically assess health services, understand the context in which indicators were developed, and solve problems related to structural management.

Therefore, the measurement of vital signs is an important indicator of safe care delivery, while its effective control is influenced by an organizational culture of active safety, which should be in agreement with the review of working processes, accessibility to basic material, and especially should consider healthcare workers, the main partners in the delivery of quality care.

\section{REFERENCES}

1. Potter PA, Perry AG. Fundamentos de enfermagem. $7^{\mathrm{a}}$ ed. Rio de Janeiro (RJ): Elsevier; 2011. 
2. Chester JG, Rudolph JL. Vital signs in older patients: age-related changes. J Am Med Dir Assoc. 2011 Jun; 12(5):337-43.

3. Cunha UGV, Valle EA, Melo RA. O exame físico do idoso. In: Freitas EV, Py L, Cançado Fax, Doll J, Gorzoni ML. Tratado de Geriatria e Gerontologia. $3^{\text {a }}$ ed. Rio de Janeiro (RJ): Guanabara Koogan; 2011. p. $985-1000$.

4. Sociedade Brasileira de Cardiologia, Sociedade Brasileira de Hipertensão; Sociedade Brasileira de Nefrologia. VI Diretrizes Brasileiras de hipertensão. Arq Bras Cardiol. 2010; 95(Suppl 1):1-51

5. Seman AP, Faria LFC, Paula LHB, Nedel S. Hipertermia e hipotermia. In: Freitas EV, Py L, Cançado Fax, Doll J, Gorzoni ML. Tratado de Geriatria e Gerontologia. $3^{\mathrm{a}}$ ed. Rio de Janeiro (RJ): Guanabara Koogan; 2011. p. 1149-61.

6. Churpek MM, Yuen TC, Winslow C, Hall J, Edelson DP. Differences in vital signs between elderly and nonelderly patients prior to ward cardiac arrest. Crit Care Med. 2015 Apr; 43(4):816-22.

7. Culo S. Risk assessment and intervention for vulnerable older adults. BCMJ. 2011 Oct; 53 (8):421-5.

8. Morosini S, Marques APO, Leal MCC, Marino JG, Melo HMA. Custo e tempo de permanência hospitalar de idosos residentes em Recife-PE. Geriatria e Gerontologia. 2011; 5(2):91-8.

9. Rantz MJ, Skubic M, Popescu M, Galambos C, Koopman RJ, Alexander GL, et al. A New Paradigm of technology-enabled 'vital signs' for early detection of health change for older adults. Gerontology. 2015; 61(3):281-90.

10. Dupouy J, Moulis G, Tubery M, Ecoiffier M, Sommet A, Poutrain JC, et al. Which adverse events are related to health care during hospitalization in elderly inpatients? Int J Med Sci. 2013 Jul; 10(9):1224-30.

11. World Health Organization. World alliance for patient safety. Taxonomy. The conceptual framework for the international classification for patient safety. Genebra (SW): WHO; 2009.

12. Storm-Versloot MN, Verweij L, Lucas C, Ludikhuize J, Goslings JC, Legemate DA, et al. Clinical relevance of routinely measured vital signs in hospitalized patients: a systematic review. J Nurs Scholarsh. 2014 Jan; 46(1):39-49.

13. Elliott M, Coventry A. Critical care: the eight vital signs of patient monitoring. Br J Nurs. 2012 MayJun; 21(10):621-5.

14. Guedes GG, Trevisan DD, Stancato K. Auditoria de prescrições de enfermagem de um hospital de ensino paulista: avaliação da qualidade da assistência. RAS. 2013 Abr-Jun; 15(59):71-8.

15. Brasil. Lei n. 7.498, de 25 de junho de 1986: dispõe sobre a regulamentação do exercício da Enfermagem e dá outras providências. Diário Oficial da República Federativa do Brasil, 26 Jun 1986. Seção 1.
16. Miltner RS, Johnson KD, Deierhoi R. Exploring the frequency of blood pressure documentation in emergency departments. J Nurs Scholarsh. 2014 Mar; 46(2):98-105.

17. Paranaguá TTB. Análise dos incidentes ocorridos na Clínica Cirúrgica de um hospital universitário da região Centro-Oeste [dissertação]. Goiânia (GO): Universidade Federal de Goiás, Faculdade de Enfermagem; 2011.

18. Lamantia MA, Stewart PW, Platts-Mills TF, Biese $\mathrm{KJ}$, Forbach C, Zamora E, et al. Predictive value of initial triage vital signs for critically ill older adults. West J Emerg Med. 2013 Sep; 14(5):453-60.

19. Permpongkosol S. Iatrogenic disease in the elderly: risk factors, consequences, and prevention. Clin Interv Aging. 2011 Mar; 6:77-82.

20. Szlejf C, Farfel JM, Curiati JA, Junior EBC, JacobFilho W, Azevedo RS. Medical adverse events in elderly hospitalized patients: A prospective study. Clinics. 2012 Nov; 67(11):1247-52.

21. Onder G, Van Der Cammen TJ, Petrovic M, Somers A, Rajkumar C. Strategies to reduce the risk of iatrogenic illness in complex older adults. Age Ageing. 2013 May; 42(3):284-91.

22. Ludikhuize J, Smorenburg SM, de Rooij SE, de Jonge E. Identification of deteriorating patients on general wards; measurement of vital parameters and potential effectiveness of the Modified Early Warning Score. J Crit Care. 2012 Aug; 27(4):424 e 7-13.

23. Chen J, Hillman K, Bellomo R, Flabouris A, Finfer $\mathrm{S}$, Cretikos $\mathrm{M}$. The impact of introducing medical emergency team system on the documentations of vital signs. Resuscitation. 2009 Jan; 80(1):35-43.

24. McGain F, Cretikos MA, Jones D, Van Dyk S, Buist MD, Opdam H, et al. Documentation of clinical review and vital signs after major surgery. Med J Aust. 2008 Oct; 189(7):380-3.

25. Cretikos MA, Bellomo R, Hillman K, Chen J, Finfer S, Flabouris A. Respiratory rate: the neglected vital sign. Med J Aust. 2008 Jun; 188(11):657-59.

26. Lusardi M. Is Walking Speed a Vital Sign? Absolutely! Top Geriatr Rehabil. 2012 Apr-Jun; 28(2):67-76.

27. Fontanella BJB, Luchesi BM, Saidel MGB, Ricas J, Turato ER, Melo DG. Amostragem em pesquisas qualitativas: proposta de procedimentos para constatar saturação teórica. Cad Saúde Pública. 2011 Feb; 27(2):388-94.

28. Bardin L. Análise de conteúdo. 70ª ed. Lisboa (PT): Edições 70; 2011.

29. Rosenstock IM. The health belief model and preventive health behavior. Health Educ Monogr. 1974; 2(4):354-86.

30. Ministério da Saúde (BR). Conselho Nacional de Saúde. Resolução n. 466, de 12 de dezembro de 2012. Diretrizes e normas regulamentadoras para 
pesquisas envolvendo seres humanos. Brasília (DF): MS; 2012.

31. Souza AS, Andrade CC, Reis Junior AP, Meira EC, Menezes MR, Gonçalves LHT. Atendimento ao idoso hospitalizado: percepções de profissionais de saúde. Cienc Cuid Saude. 2013 Abr-Jun; 12(2):274-81

32. Pires CGS; Mussi FC. Crenças em saúde para o controle da hipertensão arterial. Ciênc saúde coletiva. 2008 Dec; 13(suppl 2):2257-67.

33. Fontana RT. Humanização no processo de trabalho em enfermagem: uma reflexão. Rev Rene. 2010 JanMar; 11(1):200-7.

34. World Health Organization. The Conceptual Framework for the International Classification for Patient Safety. Version 1.1. Final Technical Report and Technical Annexes. Geneva: WHO; 2009.

35. Donabedian A. The definition of quality: approaches to its assessment. Ann Arbor (US): Health Administration Press; 1980.

36. Salum NC, Prado ML. A educação permanente no desenvolvimento de competências dos profissionais de enfermagem. Texto Contexto Enferm [online]. 2014 Abr-Jun [acesso 2015 Jul 09]; 23(2):301-8. Disponível em: http://www.scielo.br/pdf/tce/ v23n2/pt_0104-0707-tce-23-02-00301.pdf

37. Jesus MCP, Figueiredo MAG, Santos SMR, Amaral AMM, Rocha LO, Thiollent MJM. Educação permanente em enfermagem em um hospital universitário. Rev Esc Enferm USP. 2011; 45(5):1229-36.

38. Bezerra ALQ, Queiroz ES, Weber J, Munari DB. O processo de educação continuada na visão de enfermeiros de um hospital universitário. Rev Eletr Enf [online]. 2012 Jul-Sep [acesso 2015 Jul 09]; 14(3):618-25. Disponível em: https:/ / www.fen.ufg. br/fen_revista/v14/n3/pdf/v14n3a19.pdf 